\title{
Diferensiasi Leukosit Ikan Lele Dumbo (Clarias gariepinus) yang diberi Pakan Mengandung Kunyit (Curcuma domestica Val.) dan Diinfeksi Bakteri Aeromonas hydrophila
}

\section{Leukocyte Differentiation of African Catfish (Clarias gariepinus) with a Diet Containing Turmeric (Curcuma domestica Val) and Infected with Aeromonas hydrophila}

\author{
Kiky Dirgantara Ginting $^{1 *}$, Morina Riauwaty ${ }^{1}$, Henni Syawal ${ }^{1}$ \\ ${ }^{1}$ Jurusan Budidaya Perairan, Fakultas Perikanan dan Kelautan, Universitas Riau \\ email:kiky.ginting08@gmail.com
}

(Received: 01 Juni 2021; Accepted: 28 Juni 2021)

\begin{abstract}
ABSTRAK
Penelitian ini dilaksanakan pada bulan Agustus sampai Oktober 2020 di Laboratorium Parasit dan Penyakit Ikan, Jurusan Budidaya Perairan, Fakultas Perikanan dan Kelautan, Universitas Riau. Penelitian ini bertujuan untuk mendapatkan dosis terbaik pemberian pakan mengandung kunyit (Curcuma domestica Val.) pada ikan lele dumbo (Clarias gariepinus) untuk mencegah infeksi Aeromonas hydrophila. Metode yang digunakan adalah metode eksperimen dengan menggunakan Rancangan Acak Lengkap (RAL) satu faktor lima taraf perlakuan dan 3 kali ulangan. Perlakuan yang diterapkan adalah Kn (kontrol, tanpa kunyit), Kp (tanpa kunyit dan diuji tantang dengan A. hydrophila), P1 (0,5 g kunyit/kg pelet dan diuji tantang dengan A. hydrophila), P2 $(0,7 \mathrm{~g} / \mathrm{kg})$, P3 $(0,9 \mathrm{~g} / \mathrm{kg}$ pelet). Ikan dipelihara selama 45 hari dalam akuarium berukuran 40x30x30 cm dengan padat tebar 1 ekor/ $3 \mathrm{~L}$ air. Uji tantang dengan A. hydrophila kepadatan $10^{8}$ CFU/mL sebanyak $0,1 \mathrm{~mL} /$ ekor dilakukan pada hari ke-30. Setelah uji tantang ikan kembali dipelihara hingga hari ke- 45. Pada perlakuan Kp dan P1 menunjukkan gejala klinis berupa produksi lendir berlebih, warna pucat, pergerakan tidak normal, mata buram, nafsu makan berkurang, dan sirip geripis. Pemberian pakan mengandung kunyit pada ikan lele dumbo untuk mencegah infeksi $A$. hydrophila. Dosis terbaik pemberian pakan mengandung kunyit adalah 0,9 $\mathrm{g} / \mathrm{kg}$ pelet yang ditandai dengan total leukosit $11,29 \times 10^{4} \mathrm{sel} / \mathrm{mm}^{3}$, kadar leukokrit $1,33 \%$, limfosit $79,66 \%$, monosit $12,00 \%$, neutrofil $7,00 \%$, aktivitas fagositosis $34,66 \%$, dan kelulushidupan ikan $80,00 \%$.
\end{abstract}

Kata Kunci: Ikan Lele Dumbo, Aeromonas hydrophila, Kunyit, Hematologi

\begin{abstract}
This research was conducted from August to October 2020 at the Laboratory of Fish Parasites and Diseases, Department of Aquaculture, Faculty of Fisheries and Marine, University of Riau. This study aims to obtain the best dose of feeding containing turmeric (Curcuma domestica Val.) in African catfish (Clarias gariepinus) to prevent Aeromonas hydrophila infection. The method used is an experimental method using a Completely Randomized Design (CRD) one factor five treatment levels and 3 replications. The treatments applied were $\mathrm{Kn}$ (control, no turmeric), Kp (no turmeric and tested against with A. hydrophila), P1 (0.5 g turmeric/kg of pellets and tested against with A. hydrophila), P2 $(0.7 \mathrm{~g} / \mathrm{kg})$, P3 $(0.9 \mathrm{~g} / \mathrm{kg})$. Fish were reared for 45 days in a $40 \times 30 \times 30 \mathrm{~cm}$ aquarium with a stocking density of $1 \mathrm{fish} / 3 \mathrm{~L}$ of water. The challenge test was carried out on the 30th day using A. hydrophila with a density of $10^{8} \mathrm{CFU} / \mathrm{ml}$. After the challenge test, the fish were reared again until the 45th day. Kp and P1 treatments showed clinical symptoms with excess mucus, skin lesions, abnormal movement, exophthalmia, low appetite, and fin flakes. Feeding containing turmeric has a significant effect on leukocytes differentiation of African catfish to prevent A. hydrophila. The best dose of feeding containing turmeric is $0.9 \mathrm{~g} / \mathrm{kg}$ of pellets which
\end{abstract}


was marked by total leukocytes of $11.29 \times 10^{4}$ cells $/ \mathrm{mm}^{3}$, a leukocyte levels of $1.33 \%$, a lymphocytes of $79.66 \%$, a monocytes of $12.00 \%$, a neutrophils of $7.00 \%$, a phagocytosis activity of $34.66 \%$, and a fish survival of $80.00 \%$.

Keyword: African Catfish, Aeromonas hydrophila, Turmeric, Hematology

\section{Pendahuluan}

Ikan lele dumbo (Clarias gariepinus) merupakan komoditas perikanan yang banyak dibudidayakan oleh masyarakat Indonesia. Wadah pemeliharaan ikan lele adalah kolam, keramba jaring apung, dan sawah. Produksi ikan lele dari tahun 2017 - 2018 naik dari 841,75 ribu ton menjadi 1,81 juta ton dengan peningkatan produksi $114,82 \%$ (Kementerian Kelautan dan Perikanan, 2018).

Budidaya ikan lele dumbo dengan padat tebar tinggi memiliki kendala serangan penyakit yang disebabkan oleh Aeromonas hydrophila. Kerugian ekonomi berupa kematian ikan lele dan kegagalan panen yang dialami akan terjadi jika serangan penyakit tidak dapat ditanggulangi. Oleh karena itu sangat penting dilakukan suatu upaya pencegahan serangan penyakit.

Salah satu bahan alami yang dapat digunakan sebagai antibakteri adalah kunyit. Senyawa utama yang terkandung dalam rimpang kunyit adalah minyak atsiri dan kurkuminoid (Kusbiantoro dan Purwaningrum, 2018). Penggunaan kunyit diketahui memiliki beberapa efek farmakologi seperti antiinflamasi, antioksidan, antibakteri, antivirus, antifungi, dan antimalaria (Shan dan Iskandar, 2018).

Menurut Christy et al. (2019), bakteri A.hydrophila menimbulkan wabah penyakit dengan tingkat kematian $80-100 \%$ dalam waktu 1-2 minggu. Sensitivitas kunyit terhadap bakteri Aeromonas sp. sebesar 13 $\mathrm{mm}$ dan toksisitas $\mathrm{LD}_{50}$, yaitu $1,54 \mathrm{~g} / \mathrm{L}$ (Riauwaty, 2015 dalam Andesra et al., 2019). Menurut Iman et al. (2016) penggunanan kunyit dalam pakan ikan dengan konsentrasi $0,7 \mathrm{~g} / \mathrm{kg}$ pakan mampu meningkatkan leukosit ikan patin (Pangasius hypopthalmus) sebesar $12,01 \times 10^{4} \mathrm{sel} / \mathrm{mm}^{3}$ dan keluslushidupan ikan $100 \%$ terhadap serangan bakteri A.hydrophila .

Kesehatan ikan dapat dilihat dari gambaran sel darah, salah satunya adalah sel darah putih. Adanya infeksi bakteri pada ikan dapat menyebabkan terjadinya perubahan gambaran sel darah putih seperti total leukosit, diferensiasi leukosit, dan aktivitas fagositosis.
Sel darah putih mempunyai peranan dalam sistem kekebalan tubuh ikan (Simorangkir et al., 2020).

\section{Metode Penelitian}

2.1. Waktu dan Tempat

Penelitian ini dilaksanakan pada bulan Agustus sampai Oktober 2020 di Laboratorium Parasit dan Penyakit Ikan, Jurusan Budidaya Perairan, Fakultas Perikanan dan Kelautan Universitas Riau.

\subsection{Metode Penelitian}

Metode yang digunakan dalam penelitian ini adalah metode eksperimen dengan Rancangan Acak Lengkap (RAL) satu faktor dengan lima taraf perlakuan, untuk mengurangi tingkat kekeliruan maka dilakukan ulangan sebanyak tiga kali sehingga diperlukan 15 unit percobaan. Perlakuan yang digunakan pada penelitian ini adalah:

$\mathrm{Kn}=$ Pemberian pakan tidak mengandung kunyit dan tidak diuji tantang dengan bakteri $A$. hydrophila.

$\mathrm{Kp}=$ Pemberian pakan tidak mengandung kunyit dan diuji tantang dengan bakteri A. hydrophila.

$\mathrm{P} 1=$ Pemberian pakan mengandung kunyit dengan dosis $0,5 \mathrm{~g} / \mathrm{kg}$ pakan.

$\mathrm{P} 2=$ Pemberian pakan mengandung kunyit dengan dosis $0,7 \mathrm{~g} / \mathrm{kg}$ pakan

$\mathrm{P} 3=$ Pemberian pakan mengandung kunyit dengan dosis $0,9 \mathrm{~g} / \mathrm{kg}$ pakan.

\subsection{Prosedur Penelitian}

\subsubsection{Persiapan Wadah dan Ikan Uji}

Wadah yang digunakan adalah akuarium berukuran $(40 \times 30 \times 30) \mathrm{cm}$ sebanyak 15 unit. Setiap wadah yang digunakan selama penelitian terlebih dahulu disterilkan dengan Kalium Permanganat. Air pada wadah tersebut dibiarkan selama 24 jam. Selanjutnya wadah dicuci dengan air bersih dan dikeringkan. Kemudian akuarium diisi dengan air setinggi $25 \mathrm{~cm}(30 \mathrm{~L})$ untuk media pemeliharaan ikan. Setelah itu, akuarium diberi aerasi. 
Ikan uji yang digunakan adalah ikan lele dumbo berukuran $8-12 \mathrm{~cm}$ sebanyak 150 ekor yang diperoleh dari Meka Farm, Jln. Naga Sakti, Kecamatan Tampan, Pekanbaru. Ikan dimasukkan sebanyak 10 ekor ke dalam masing-masing akuarium. Pemeliharaan ikan dilakukan selama 45 hari dan selama pemeliharaan ikan diberi pakan sesuai dengan perlakuan. Pemberian pakan dilakukan tiga kali sehari, yaitu pada pukul 08.00, 12.00 dan 18.00 WIB secara ad satiation. Pengamatan dilakukan di awal, hari ke- 30 pemeliharaan, dan 14 hari pasca uji tantang.

\subsubsection{Persiapan Pakan Uji}

Kunyit diperoleh dari pasar tradisional yang ada di Pekanbaru. Kunyit terlebih dahulu dicuci, selanjutnya dipotong tipis, dan dijemur. Setelah penjemuran, kunyit diblender kemudian diayak untuk mendapatkan hasil kunyit yang halus. Pakan ikan yang digunakan adalah pakan komersil jenis F-999 dengan kandungan protein sebesar 35\%. Penambahan kunyit dalam pakan dilakukan dengan cara mengencerkan kunyit sesuai dengan dosis ke dalam akuades sebanyak $250 \mathrm{~mL}$ yang telah dipanaskan. Selanjutnya larutan disemprot ke pakan komersil dengan menggunakan sprayer sedikit demi sedikit sampai merata kemudian dikeringanginkan.

\subsubsection{Penyediaan Isolat $A$. hydrophila dan Uji Tantang}

Isolat A.hydrophila diperoleh dari koleksi pada Laboratorium Parasit dan Penyakit Ikan Fakultas Perikanan dan Kelautan Universitas Riau, isolat diperbanyak pada media GSP (GSP media selectif untuk A.hydrophila), kemudian diinkubasi dalam incubator selama 18-24 jam Setelah 24 jam, biakkan bakteri dikultur kembali ke dalam media TSB yang baru. Setelah 24 jam, media tersebut dapat digunakan untuk uji tantang.

Ikan diuji tantang dengan bakteri $A$. hydrophila $10^{8} \quad \mathrm{CFU} / \mathrm{mL}$ sebanyak 0,1 $\mathrm{ml} /$ ekor di hari ke- 31 pemeliharaan. Sebelum uji tantang, dilakukan pembiusan menggunakan minyak cengkeh. Kemudian dilakukan penyuntikan secara intramuscular menggunakan spuit ukuran $1 \mathrm{~mL}$. Setelah itu, ikan dikembalikan ke dalam akuarium dan dipelihara selama 14 hari sesuai dengan dosis pakan perlakuan.

\subsubsection{Pengambilan Darah Ikan}

Pengambilan darah ikan uji dilakukan sebanyak tiga kali, yaitu awal, hari ke- 30 pemeliharan dan 14 hari pasca uji tantang A.hydrophila. Pengambilan darah dilakukan dengan cara, terlebih dahulu ikan uji dibius dengan minyak cengkeh dengan dosis 0,1 $\mathrm{mL} / \mathrm{L}$ air. Pengambilan darah ikan dilakukan dengan menggunakan syringe $1 \mathrm{~mL}$ yang telah dibasahi dengan EDTA. Pengambilan darah ikan dilakukan pada bagian vena caudalis. Darah yang telah diambil dimasukkan ke dalam tabung eppendorf yang sudah dibasahi EDTA dan selanjutnya digunakan untuk pengamatan total leukosit, kadar leukokrit, diferensiasi leukosit dan aktivitas fagositosis.

\subsubsection{Pengamatan Gejala Klinis}

Pengamatan gejala klinis meliputi perubahan morfologi (luka/borok, mata menonjol, dan sirip rusak/geripis). Pengamatan gejala klinis diamati setiap 24 jam sekali selama 3 hari di hari pertama pasca uji tantang A. hydrophila. Hasil pengamatan terhadap gejala klinis disajikan dalam bentuk tabel.

\subsection{Parameter yang Diamati \\ 2.4.1. Total Leukosit}

Prosedur perhitungan total leukosit mengacu pada Blaxhall dan Daisley dalam Iman et al. (2016), yaitu dengan cara sampel darah dihisap dari mikrotube dengan menggunakan pipet leukosit hingga skala 0,5 dan ditambah larutan Turk hingga garis 11, setelah itu dihomogenkan dengan cara menggoyanggoyangkan pipet leukosit membentuk angka delapan selama lima menit. Setelah homogen, darah dibuang sebanyak dua tetes untuk menghilangkan udara, lalu darah diteteskan pada kotak haemocytometer dan ditutup dengan cover glass. Selanjutnya diamati di bawah mikroskop dengan pembesaran 10x40. Jumlah total leukosit dihitung dengan menggunakan mikroskop pada 4 kotak besar haemocytometer dengan rumus sebagai berikut :

\section{$\sum$ Leukosit $=\sum$ n $x 50 \mathrm{sel} / \mathrm{mm}^{3}$}

Keterangan :

$\sum \mathrm{n}=$ Jumlah total leukosit pada 4 kotak besar

$50=$ Faktor pengenceran 


\subsubsection{Kadar Leukokrit}

Metode pengukuran leukokrit, yaitu sampel darah dimasukkan ke dalam tabung mikro hematocrit (tabung kapiler) hingga batas volume dan ditutup ujungnya (yang bertanda merah) dengan kretoseal kemudian disentrifuse selama 10 menit dengan kecepatan $3.500 \mathrm{rpm}$. Setelah itu diukur persentase leukokrit dengan menggunakan skala. Kadar leukokrit dinyatakan dalam persen volume padatan sel darah (Anderson dan Siwicki dalam Dosim et al., 2013).

\subsubsection{Diferensiasi Leukosit}

Perhitungan jenis leukosit berdasarkan metode Blaxhall dan Daisley (1973) dalam Kurniawan et al. (2020), yaitu dengan cara mengambil darah ikan, kemudian dibuat preparat ulas darah pada objek glass lalu dikering anginkan, selanjutnya difiksasi dengan larutan methanol selama 5 menit, setelah itu dibilas dengan akuades lalu dikeringanginkan, dan dilanjutkan dengan pewarnaan giemsa selama 20 menit, setelah itu dicuci dengan air mengalir, kemudian dikeringanginkan, lalu diamati di bawah mikroskop dengan pembesaran 10x40. Jenis leukosit yang diamati adalah limfosit, monosit, dan neutrofil. Kemudian diferensiasi leukosit dihitung dengan rumus sebagai berikut:

\section{Persentase sel $=\sum$ jumlah sel $\times 100 \%$}

\subsubsection{Aktivitas Fogositosis}

Aktivitas fagositosis diukur menurut Anderson dan Siwicki (1993) dalam Iman et al. (2016). yaitu sampel darah diambil sebanyak $50 \mu \mathrm{L}$ dan dimasukkan ke dalam mikrotube. Setelah itu ditambahkan sebanyak $50 \mu \mathrm{L}$ suspensi Staphylococcus aereus dengan kepadatan $10^{7} \mathrm{sel} / \mathrm{mL}$. Kemudian, suspensi tersebut dihomogenkan dan diinkubasi dalam inkubator selama 20 menit.Sebanyak $5 \mu \mathrm{L}$ suspensi tersebut diambil dan dibuat preparat ulas darah. Darah sampel diambil dan diteteskan pada gelas objek pada bagian sisi kanan. Gelas objek lain diletakkan disebelah kanan darah membentuk sudut $30^{\circ}$. Gelas objek tersebut ditarik ke arah kiri dengan tetap menyentuh darah tersebut hingga membentuk preparat ulas darah yang cukup tipis sehingga mudah diamati. Setelah itu, preparat ulas dikeringanginkan. Preparat ulas yang telah kering lalu difiksasi dalam larutan methanol selama 3-5 menit. Setelah itu, preparat ulas dikeringanginkan. Preparat ulas direndam dalam larutan Giemsa selama 15 menit. Selanjutnya dibilas dengan akuades dan kembali dikeringanginkan, Setelah itu, preparat ulas dapat diamati di bawah mikroskop.

\subsubsection{Tingkat Kelulushidupan}

Menurut Kelulushidupan Menurut Weatherley (1972) dalam Muchdar dan Juharni (2017), tingkat kelulushidupan dapat dihitung dengan rumus sebagai berikut:

$$
S R=\frac{N t}{N o} \times 100 \%
$$

Keterangan:

$\mathrm{SR}=$ Kelulushidupan $(\%)$

$\mathrm{Nt}=$ Jumlah ikan yang hidup pada akhir penelitian (ekor)

No = Jumlah ikan yang hidup pada awal penelitian (ekor)

\subsection{Analisis Data}

Data yang diperoleh selama penelitian disajikan dalam bentuk tabel kemudian dihitung. Selanjutnya data dianalisa secara statistik menggunakan software IBM SPSS versi 22.

\section{Hasil dan Pembahasan \\ 3.1. Gejala Klinis}

Pengamatan gejala klinis ikan lele dumbo pasca uji tantang A.hydrophila menunjukkan bahwa ikan pada perlakuan $\mathrm{Kn}$ tidak menunjukkan gejala klinis apapun. Hal ini dikarenakan pada perlakuan Kn, ikan tidak diuji tantang A.hydrophila. Pada perlakuan Kp dan P1 menunjukkan gejala klinis berupa produksi lendir berlebih, warna pucat, pergerakan tidak normal, mata buram, nafsu makan berkurang, dan sirip geripis. Lebih jelas dapat dilihat pada Gambar 1.

Gejala klinis pada perlakuan P2 dan P3 adalah produksi lendir berlebih, pergerakan lambat, warna cerah, mata normal, nafsu makan berkurang, dan sirip punggung geripis. Ikan lele dumbo yang diuji tantang A.hydrophila mengalami ulcer pada daerah bekas suntikan (Gambar 1). Menurut Kusdarwati et al. (2017) bakteri A. hydrophila mengeluarkan lesitinase dalam berusaha masuk ke aliran darah dan langsung menuju ginjal untuk berkembang biak. 
Penyembuhan luka pada perlakuan P3 terjadi lebih cepat dan lebih baik jika dibandingkan dengan perlakuan lainnya yang diuji tantang A. hydrophila. Hal ini diduga karena sudah terbentuknya imunitas tubuh ikan yang sudah diberi pakan mengandung kunyit. Pada perlakuan P1 dan P2 penyembuhan belum terjadi secara sempurna

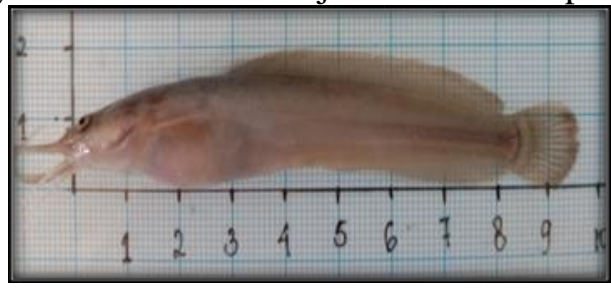

$\mathrm{Kn}$

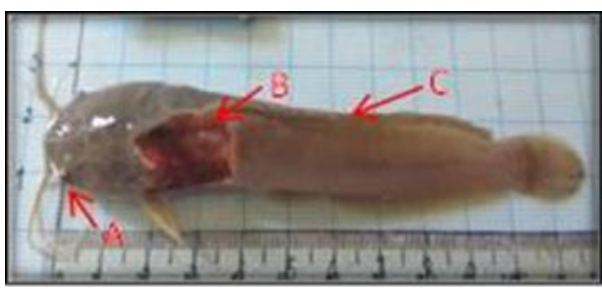

$\mathrm{P} 1$ sedangkan pada perlakuan Kp luka masih lebar dan terdapat adanya nanah. Menurut Haryani et al. (2012), bahwa senyawa fenol dari tumbuhan memiliki kemampuan untuk membentuk senyawa kompleks dengan protein melalui ikatan hidrogen, sehingga dapat merusak membran sel bakteri.
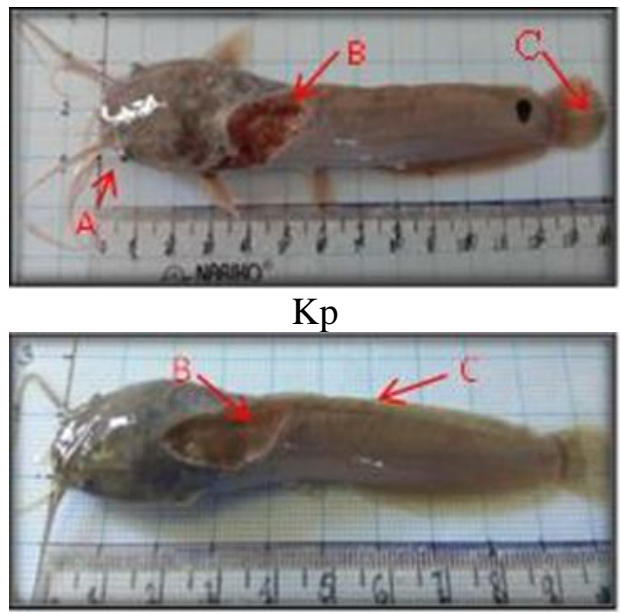

P2

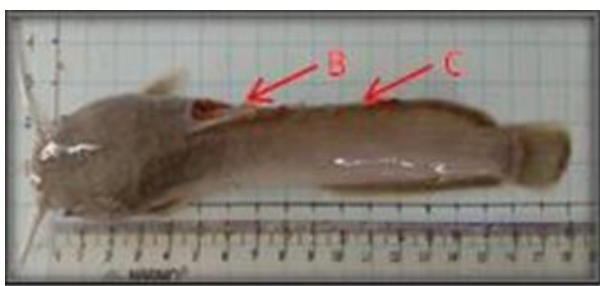

P3

Gambar 1. Gejala klinis ikan lele dumbo (C. gariepinus) pasca uji tantang dengan A.hydrophila (pengamatan di hari ke- 3)

Keterangan: $\mathrm{A}=$ Mata Menonjol; $\mathrm{B}=$ Ulcer $; \mathrm{C}=$ Sirip Geripis

\subsection{Total Leukosit}

Total leukosit ikan lele dumbo awal penelitian berkisar antara $8,18-8,43 \times 10^{4}$ $\mathrm{sel} / \mathrm{mm}^{3}$ (Tabel 1). Hasil dari uji statistik analisa variansi (ANOVA), menunjukkan bahwa pemberian pakan mengandung kunyit memberikan pengaruh nyata terhadap total leukosit ikan lele dumbo setelah 30 hari pemeliharaan $(\mathrm{P}<0,05)$. Hasil uji lanjut
Newman-Keuls menunjukkan Kn dan Kp berbeda nyata terhadap P1, P2, dan P3. Total leukosit ikan lele dumbo setelah diberi pakan mengandung kunyit mengalami peningkatan. Hal ini dikarenakan kurkumin dalam kunyit dapat mengaktifkan organ limfa dan ginjal untuk meningkatkan produksi leukosit (Susantie dan Manurung, 2019).

Tabel 1. Total leukosit ikan lele dumbo (C. gariepinus) selama penelitian

\begin{tabular}{llcc}
\hline Perlakuan & \multicolumn{3}{c}{ Total Leukosit $\mathbf{( 1 0}^{4} \mathbf{s e l} / \mathbf{m m}^{\mathbf{3}}$} \\
\cline { 2 - 4 } & Awal & Hari ke $\mathbf{- 3 0}$ & $\mathbf{1 4}$ hari pasca Ujitantang A. hydrophila \\
\hline Kn & $8,18 \pm 0,17$ & $8,37 \pm 0,12^{\mathrm{a}}$ & $8,59 \pm 0,31^{\mathrm{a}}$ \\
Kp & $8,26 \pm 0,15$ & $8,47 \pm 0,15^{\mathrm{a}}$ & $9,71 \pm 0,35^{\mathrm{b}}$ \\
P1 & $8,35 \pm 0,24$ & $8,87 \pm 0,20^{\mathrm{b}}$ & $10,28 \pm 0,31^{\mathrm{b}}$ \\
P2 & $8,43 \pm 0,25$ & $9,34 \pm 0,25^{\mathrm{c}}$ & $11,08 \pm 0,15^{\mathrm{c}}$ \\
P2 & $8,42 \pm 0,16$ & $9,60 \pm 0,15^{\mathrm{c}}$ & $11,29 \pm 0,45^{\mathrm{c}}$ \\
\hline
\end{tabular}

Keterangan: Superskrip yang berbeda pada kolom yang sama menunjukkan bahwa antar perlakuan berbeda nyata $(\mathrm{P}<0,05) ; \pm$ Standar Deviasi $(\mathrm{SD})$. 
Berdasarkan uji statistik analisis variansi (ANAVA) menujukkan bahwa pemberian pakan mengandung kunyit memberikan pengaruh nyata terhadap total leukosit ikan lele dumbo 14 hari pasca uji tantang $A$. hydrophila $(\mathrm{P}<0,05)$. Hasil uji lanjut Newman-Keuls menunjukkan perlakuan Kn berbeda nyata dengan Kp, P1, P2, dan P3. Total leukosit ikan lele dumbo 14 hari pasca uji tantang A.hydrophila mengalami peningkatan. Peningkatan total leukosit menunjukkan bahwa kekebalan tubuh ikan meningkat yang ditandai dengan peningkatan aktifitas sel fagosit yang berfungsi untuk melakukan fagositosis terhadap benda asing yang masuk ke dalam tubuh ikan (Wintoko et al., 2013). Ikan meningkatkan produksi leukosit sebagai respon tanggap kebal terhadap adanya benda asing yang masuk ke dalam tubuh dan kurkumin dalam kunyit dapat mengaktifkan organ limfa dan ginjal untuk meningkatkan produksi leukosit (Bertha et al., 2016).

\subsection{Diferensiasi Leukosit}

Diferensiasi leukosit ikan lele dumbo selama penelitian dari awal, hari ke-30 pemeliharaan dengan pemberian pakan mengandung kunyit dan 14 hari pasca uji tantang A. hydrophila dapat dilihat pada Tabel 2.

Tabel 2. Diferensiasi leukosit ikan lele dumbo (C. gariepinus) selama penelitian

\begin{tabular}{|c|c|c|c|c|}
\hline $\begin{array}{c}\text { Diferensiasi } \\
\text { Leukosit }\end{array}$ & Perlakuan & Limfosit (\%) & Monosit (\%) & Neutrofil (\%) \\
\hline \multirow{5}{*}{$\begin{array}{c}\text { Awal } \\
\text { Pemeliharaan }\end{array}$} & Kn & $72,66 \pm 1,15$ & $15,66 \pm 1,52$ & $11,66 \pm 0,57$ \\
\hline & $\mathrm{Kp}$ & $71,00 \pm 2,00$ & $14,66 \pm 1,52$ & $14,33 \pm 1,52$ \\
\hline & $\mathrm{P} 1$ & $71,66 \pm 2,08$ & $15,66 \pm 1,52$ & $12,66 \pm 2,51$ \\
\hline & $\mathrm{P} 2$ & $72,33 \pm 1,52$ & $15,00 \pm 2,00$ & $12,66 \pm 3,21$ \\
\hline & P3 & $73,33 \pm 1,52$ & $15,33 \pm 2,08$ & $11,33 \pm 0,57$ \\
\hline \multirow{5}{*}{$\begin{array}{c}\text { Hari Ke- } 30 \\
\text { Pemeliharaan }\end{array}$} & $\mathrm{Kn}$ & $75,66 \pm 2,08^{a}$ & $11,66 \pm 1,52^{b}$ & $12,66 \pm 0,57^{\mathrm{c}}$ \\
\hline & $\mathrm{Kp}$ & $76,00 \pm 1,00^{\mathrm{a}}$ & $13,66 \pm 1,15^{\mathrm{b}}$ & $11,66 \pm 0,57^{\mathrm{c}}$ \\
\hline & $\mathrm{P} 1$ & $83,66 \pm 1,52^{b}$ & $6,66 \pm 1,15^{\mathrm{a}}$ & $10,00 \pm 1,00^{b}$ \\
\hline & $\mathrm{P} 2$ & $86,33 \pm 1,52^{b c}$ & $7,33 \pm 1,52^{\mathrm{a}}$ & $7,00 \pm 1,00^{\mathrm{a}}$ \\
\hline & P3 & $89,00 \pm 2,00^{\mathrm{c}}$ & $5,33 \pm 1,15^{\mathrm{a}}$ & $6,33 \pm 0,57^{\mathrm{a}}$ \\
\hline \multirow{5}{*}{$\begin{array}{l}\text { 14 Hari Pasca } \\
\text { Uji Tantang A. } \\
\text { hydrophila }\end{array}$} & $\mathrm{Kn}$ & $74,66 \pm 1,15^{b}$ & $13,00 \pm 1,00^{\mathrm{c}}$ & $12,00 \pm 1,00^{\mathrm{c}}$ \\
\hline & $\mathrm{Kp}$ & $72,00 \pm 1,00^{\mathrm{a}}$ & $9,66 \pm 0,57^{\mathrm{a}}$ & $17,66 \pm 0,57^{\mathrm{d}}$ \\
\hline & $\mathrm{P} 1$ & $78,66 \pm 1,52^{\mathrm{c}}$ & $10,33 \pm 0,57^{\mathrm{ab}}$ & $10,33 \pm 0,57^{\mathrm{b}}$ \\
\hline & $\mathrm{P} 2$ & $82,33 \pm 1,52^{\mathrm{d}}$ & $11,00 \pm 1,00^{\mathrm{ab}}$ & $7,66 \pm 0,57^{\mathrm{a}}$ \\
\hline & $\mathrm{P} 3$ & $79,66 \pm 1,52^{\mathrm{c}}$ & $12,00 \pm 1,00^{\mathrm{bc}}$ & $7,00 \pm 1,00^{\mathrm{a}}$ \\
\hline
\end{tabular}

Keterangan: Superskrip yang berbeda pada kolom yang sama menunjukkan bahwa antar perlakuan berbeda nyata $(\mathrm{P}<0,05) ; \pm$ Standar Deviasi (SD).

Berdasarkan Tabel 2 dapat dilihat bahwa persentase limfosit ikan lele di awal penelitian berkisar antara 71,00-73,33\%. Menurut Preanger et al. (2016) persentase normal limfosit pada ikan lele berkisar antara $71,12-82,88 \%$.

Berdasarkan hasil uji statistik analisis varian (ANAVA) menunjukkan bahwa pemberian pakan mengandung kunyit memberikan pengaruh nyata terhadap persentase limfosit ikan lele dumbo setelah 30 hari pemeliharaan $(\mathrm{P}<0,05)$. Hasil uji lanjut studi Newman-Keuls menunjukkan bahwa Kn dan Kp berbeda nyata terhadap P1, P2 dan P3. Persentase sel limfosit ikan lele dumbo setelah diberi pakan mengandung kunyit mengalami peningkatan. Menurut Lestari et al. (2019), peningkatan persentase limfosit merupakan salah satu tanda keberhasilan sistem imunitas dalam mengembangkan respons imun seluler (non spesifik).

Berdasarkan hasil uji statistik analisis variansi (ANAVA) menunjukkan bahwa pemberian pakan mengandung kunyit memberikan pengaruh nyata terhadap persentase limfosit ikan lele dumbo 14 hari pasca uji tantang A.hydrophila $(\mathrm{P}<0,05)$. Hasil uji lanjut studi Newman-Keuls menunjukkan Kn berbeda nyata dengan Kp, P1, P2, dan P3. Persentase limfosit ikan lele dumbo 14 hari 
pasca uji tantang A. hydrophila mengalami penurunan. Menurut Rustikawati (2012), penurunan limfosit terjadi karena sebagian besar dari limfosit berpindah ke sirkulasi lain, berkompetisi ke dalam jaringan tubuh dimana terdapat peradangan.

Berdasarkan Tabel 2 dapat dilihat bahwa persentase sel monosit ikan lele dumbo di awal penelitian berkisar antara 14,6615,66\%. Menurut Preanger et al. (2016), persentase normal sel monosit pada ikan teleostei berkisar $0,1 \%$ dari populasi leukosit, namun dapat meningkat dengan cepat (sekitar 48 jam) setelah terinfeksi benda asing.

Berdasarkan hasil uji statistik analisis variansi (ANAVA) menunjukkan bahwa pemberian pakan mengandung kunyit memberikan pengaruh nyata terhadap persentase sel monosit ikan lele setelah 30 hari pemeliharaan $(\mathrm{P}<0,05)$. Hasil lanjut studi Newman-Keuls menunjukkan Kn dan Kp berbeda nyata terhadap P1, P2 dan P3. Persentase sel monosit ikan lele dumbo setelah diberi pakan mengandung kunyit mengalami penurunan. Monosit yang cenderung menurun di setiap minggunya berkaitan dengan fungsi monosit sebagai makrofag, dimana monosit tidak dibutuhkan untuk memfagosit, dikarenakan belum adanya infeksi yang masuk ke dalam tubuh yang merangasang produksi monosit (Rahma et al., 2015).

Berdasarkan hasil uji statistik analisis variansi (ANAVA) menujukkan bahwa pemberian pakan mengandung kunyit memberikan pengaruh nyata terhadap persentase sel monosit pada ikan lele dumbo 14 hari pasca uji tantang $A$. hydrophila $(\mathrm{P}<0,05)$. Hasil uji lanjut Newman-Keuls menunjukkan perlakuan $\mathrm{Kn}$ berbeda nyata dengan Kp, P1, P2, dan P3. Perlakuan Kp berbeda nyata dengan $\mathrm{P} 1, \mathrm{P} 2$, dan $\mathrm{P}$ 3.

Peningkatan persentase sel monosit ikan lele dumbo 14 hari pasca uji tantang A.hydrophila pada perlakuan yang diberi pakan mengandung kunyit merupakan hasil terbentuknya imunitas tubuh ikan dari kunyit dan adanya respons dari benda asing yang masuk ke dalam tubuh ikan. Hal ini sesuai dengan pendapat Iman et al. (2016), bahwa peningkatan sel monosit dikarenakan distimulasi oleh zat kurkumin yang berfungsi sebagai imunostimulan, peningkatan sel monosit tersebut karena distimulasi oleh senyawa kurkumin (sodium dan metil kurkumat) yang berfungsi sebagai immunostimulan yang bekerja dengan cara memfagosit bakteri.

Tabel 2 dapat dilihat bahwa persentase sel neutrofil ikan lele dumbo di awal penelitian berkisar antara 11,33-14,33\%. Menurut Preanger et al. (2016), persentase normal dari sel neutrofil pada darah ikan berkisar antara 6-8\%. setelah 30 hari pemeliharaan $(\mathrm{P}<0,05)$. Hasil lanjut studi Newman-Keuls menunjukkan $\mathrm{Kn}$ dan $\mathrm{Kp}$ berbeda nyata terhadap P1, P2 dan P3. Persentase sel neutrofil ikan lele dumbo setelah diberi pakan mengandung kunyit mengalami penurunan.

Penurunan persentase sel neutrofil diduga karena belum adanya infeksi pada tubuh ikan lele dumbo yang diberi pakan mengandung kunyit setelah 30 hari pemeliharaan. Umumnya jumlah neutrofil akan meningkat pada saat terjadi infeksi karena neutrofil akan keluar dari pembuluh darah menuju daerah yang terinfeksi (Rahma et al., 2015). Penurunan persentase sel neutrofil sebanding dengan meningkatnya persentase sel limfosit ikan lele dumbo yang diberi pakan mengandung kunyit.

Persentase sel neutrofil pada perlakuan yang diberi pakan mengan dung kunyit mengalami peningkatan lebih rendah dibandingkan dengan perlakuan Kp. Hal ini diduga karena kondisi ikan sudah mulai membaik karena zat aktif kurkumin dalam kunyit diduga mampu menekan infeksi yang terjadi. Menurut Jain (1993) dalam Rustikawati (2012), bahwa penurunan neutrofil terjadi karena mengalami autolysis setelah berhasil menekan infeksi dari mikroba atau benda asing yang masuk ke dalam ikan.

\subsection{Kadar Leukokrit}

Kadar leukokrit ikan lele dumbo di awal penelitian berkisar antara 1,33-1,66\% (Tabel 3). Menurut Titrawani (2014) kisaran normal leukokrit ikan berkisar antara 1-2\%. Leukokrit secara umum memberikan respon terhadap semua antigen maupun mikroorganisme, kemudian dipresentasikan kepada sel $\mathrm{T}$ yang bersifat seluler (Cell Mediated Imunity) (Purbomartono et al., 2019). 
Tabel 3. Kadar Leukokrit Ikan Lele Dumbo (C. gariepinus)

\begin{tabular}{llll}
\hline \multirow{2}{*}{ Perlakuan } & \multicolumn{3}{c}{ Kadar Leukokrit $(\%)$} \\
\cline { 2 - 4 } & Awal & $\begin{array}{l}\text { Hari Ke- } 30 \\
\text { Pemeliharaan }\end{array}$ & $\begin{array}{l}\text { 14 Hari Pasca Uji Tantang } \\
\text { A. hydrophila }\end{array}$ \\
\hline Kn & $1,33 \pm 0,57$ & $1,66 \pm 0,57$ & $1,66 \pm 0,57^{\mathrm{a}}$ \\
Kp & $1,66 \pm 0,57$ & $1,33 \pm 0,57$ & $3,33 \pm 0,57^{\mathrm{b}}$ \\
P1 & $1,33 \pm 0,57$ & $1,33 \pm 0,57$ & $2,33 \pm 0,57^{\mathrm{ab}}$ \\
P2 & $1,66 \pm 0,57$ & $1,33 \pm 0,57$ & $1,66 \pm 0,57^{\mathrm{a}}$ \\
P3 & $1,66 \pm 0,57$ & $1,33 \pm 0,57$ & $1,33 \pm 0,57^{\mathrm{a}}$ \\
\hline
\end{tabular}

Keterangan: Superskrip yang berbeda pada kolom yang sama menunjukkan bahwa antar perlakuan berbeda nyata $(\mathrm{P}<0,05) ; \pm$ Standar Deviasi $(\mathrm{SD})$.

Peningkatan kadar leukokrit pada perlakuan $\mathrm{Kp}$ dan $\mathrm{P} 1$ diduga karena infeksi yang disebabkan oleh bakteri A. hydrophila. Menurut Anderson dan Siwicki (1995) dalam Syaieba et al. (2019), bahwa kadar leukokrit rendah, kemungkinan terjadi infeksi kronis, kualitas nutrisi rendah, kekurangan vitamin serta adanya kontaminan, bila kadar leukokrit tinggi, disebakan terjadinya tahap awal infeksi dan stress.

\subsection{Aktivitas Fagositosis}

Aktivitas fagositosis ikan lele dumbo $(C$. gariepinus) selama penelitian dapat dilihat pada Tabel 4.

Tabel 4. Aktivitas Fagositosis Ikan Lele Dumbo (C. gariepinus)

\begin{tabular}{llll}
\hline \multirow{2}{*}{ Perlakuan } & \multicolumn{3}{c}{ Aktivitas Fagositosis $(\%)$} \\
\cline { 2 - 4 } & Awal & $\begin{array}{l}\text { Hari Ke- 30 } \\
\text { Pemeliharaan }\end{array}$ & $\begin{array}{l}\text { 14 Hari Pasca Uji } \\
\text { Tantang A. hydrophila }\end{array}$ \\
\hline Kn & $20,00 \pm 1,00$ & $22,00 \pm 1,73^{\mathrm{a}}$ & $21,66 \pm 1,52^{\mathrm{b}}$ \\
Kp & $19,66 \pm 0,57$ & $23,00 \pm 1,00^{\mathrm{a}}$ & $18,00 \pm 2,00^{\mathrm{a}}$ \\
P1 & $21,66 \pm 1,15$ & $24,33 \pm 1,15^{\text {ab }}$ & $28,66 \pm 1,15^{\mathrm{c}}$ \\
P2 & $21,00 \pm 1,00$ & $26,00 \pm 1,00^{\mathrm{bc}}$ & $34,00 \pm 1,73^{\mathrm{d}}$ \\
P3 & $21,00 \pm 2,00$ & $27,33 \pm 1,15^{\mathrm{c}}$ & $34,66 \pm 0,57^{\mathrm{d}}$ \\
\hline
\end{tabular}

Keterangan: Superskrip yang berbeda pada kolom yang sama menunjukkan bahwa antar perlakuan berbeda nyata $(\mathrm{P}<0,05) ; \pm$ Standar Deviasi $(\mathrm{SD})$.

Berdasarkan Tabel 4 dapat dilihat bahwa aktivitas fagositosis ikan lele dumbo di awal penelitian berkisar antara 19,66-21,66\%. Proses fagositosis dipengaruhi oleh faktor pergerakan sel fagositiik karena adanya rangsangan benda asing dan kerentanan benda asing untuk difagositosis (Rizkiyah, 2018). Aktivitas fagositosis ikan lele dumbo setelah diberi pakan mengandung kunyit mengalami peningkatan. Menurut Pangestika et al. (2012) senyawa Tetrahidrokurkumin (THC) yang merupakan senyawa turunan kurkumin yang mampu menstimulasi aktivitas sel.

\subsection{Tingkat Kelulushidupan Ikan}

Kelulushidupan ikan lele dumbo setelah 30 hari pemeliharaan adalah $100 \%$. Hal ini dapat dapat disimpulkan bahwa ikan dalam keadaan sehat. Hasil penelitian menunjukkan bahwa pemberian pakan mengandung kunyit dapat meningkatkan kelulushidupan ikan lele dumbo hingga $80 \% 14$ hari pasca uji tantang A. hydrophila. Persentase kelulushidupan ikan yang diberi pakan mengandung kunyit lebih tinggi dibandingkan dengan perlakuan $\mathrm{Kp}$ yang hanya mencapai $43,33 \%$. Lebih jelas dapat dilihat pada Tabel 5 .

Tabel 5. Kelusluhidupan Ikan Lele Dumbo (C. gariepinus)

\begin{tabular}{llc}
\hline \multirow{2}{*}{ Perlakuan } & \multicolumn{2}{c}{ Kelulushidupan (\%) } \\
\cline { 2 - 3 } & $\begin{array}{l}\text { Hari Ke- 30 } \\
\text { Pemeliharaan }\end{array}$ & $\begin{array}{c}\text { 14 Hari Pasca Uji Tantang } A . \\
\text { hydrophila }\end{array}$ \\
\hline Kn & 100 & $100,00 \pm 0,00^{\mathrm{d}}$ \\
Kp & 100 & $43,33 \pm 5,77^{\mathrm{a}}$ \\
P1 & 100 & $50,00 \pm 10,00^{\mathrm{a}}$ \\
P2 & 100 & $66,66 \pm 5,77^{\mathrm{b}}$ \\
P3 & 100 & $80,00 \pm 10,00^{\mathrm{d}}$ \\
\hline
\end{tabular}

Keterangan: Superskrip yang berbeda pada kolom yang sama menunjukkan bahwa antar perlakuan berbeda nyata $(\mathrm{P}<0,05) ; \pm$ Standar Deviasi $(\mathrm{SD})$. 
Kunyit dapat mencegah infeksi A.hydrophila dikarenakan memiliki senyawasenyawa kimia yang bersifat antiseptic dan antibakteri, seperti tannin, flavonoid, alkaloid, kurkuminoid, dansaponin (Pane et al., 2018). Kunyit berfungsi untuk meningkatkan kerja organ pencernaan yang dapat membantu penyerapan makanan dalam tubuh dan juga berfungsi untuk meningkatkan daya tahan tubuh (Pujianti et al., 2013). Wahjuningrum et al. (2014) menyatakan bahwa penambahan ekstrak kunyit dalam pakan untuk pencengahan bakteri Edwardsiella tarda dengan dosis 1 liter ekstrak tiap $2 \mathrm{~kg}$ pakan menghasilkan kelulushidupan ikan lele $60 \%$.

\section{Kesimpulan dan Saran}

Dosis terbaik pemberian pakan mengandung kunyit adalah $0,9 \mathrm{~g} / \mathrm{kg}$ pelet yang dilihat dari total leukosit $11,29 \times 10^{4}$ $\mathrm{sel} / \mathrm{mm}^{3}$, kadar leukokrit $1,33 \%$, limfosit $79,66 \%$, monosit $12,00 \%$, neutrofil $7,00 \%$, aktivitas fagositosis $34,66 \%$.

Berdasarkan hasil penelitian, maka dapat disarankan pemberian pakan mengandung kunyit dengan dosis kunyit $0,9 \mathrm{~g} / \mathrm{kg}$ pakan pada ikan lele dumbo (untuk mencegah infeksi A. hydrophila.

\section{Daftar Pustaka}

Andesra., M. Riauwaty, dan H. Syawal. (2019). Penambahan Ekstrak Kurkumin Kunyit dalam Pakan untuk Meningkatkan Kekebalan Non Spesifik Ikan Jambal Siam (Pangasius hypopthalmus) yang Dipelihara dalam Keramba. Jurnal Online Mahasiswa Bidang Perikanan dan Ilmu Kelautan 6 (1): 1-17

Bertha A., M. Riauwaty, dan I. Lukistyowati. (2016). Survival Rate of Pangasisus hypopthalmus That are Immersed in Curcumin (Curcuma domestica V) and were Infected by Aeromonas hydrophila. Jurnal Online Mahasiswa Fakultas Perikanan dan Ilmu Kelautan.

Christy, G., R. Kusdawarti, dan D. Handijatno. (2019). Determination of Aerolysin Gene Aeromonas Hydrophila by Polymerase Chain Reaction (PCR) Technique. IOP Conference Series Earth and Environmental Science 236 (1): 012097.
Dosim, E., H. Hardi, dan Agustina. (2013). Efek Penginjeksian Produk Intraseluler dan Ekstrakseluler Bakteri Pseudomonas sp. terhadap Gambaran Darah Ikan Nila (Oreochromis niloticus). Jurnal Ilmu Perikanan Tropis, 19 (1): $76-88$

Haryani, A., G. Roffi, D. Ibnu, dan S. Ayi. (2012). Uji Efektivitas Daun Pepaya (Carica papaya) untuk Pengobatan Infeksi Bakteri Aeromonas hydrophila pada Ikan Mas Koki (Carassius auratus). Jurnal Perikanan dan Kelautan 3 (3): 213-220.

Iman, K.N., M. Riauwaty, dan H. Syawal. (2016). Diferensiasi Leukosit Ikan Jambal Siam (Pangasius hypopthalmus) yang Diberi Pakan dengan Penambahan Ekstrak Kurkumin Kunyit (Curcumin domestica V.). Jurnal Online Mahasiswa Fakultas Perikanan dan Ilmu Kelautan, 4

Kementrian Kelautan dan Perikanan. (2018). Refleksi 2018 \& Outlook 2019. Jakarta. 1-68 hlm.

Kurniawan, R., H. Syawal, dan I. Effendi. (2020). Pengaruh Penambahan Suplemen Herbal pada Pakan terhadap Diferensiasi Leukosit Ikan dan Sintasan Ikan Patin (Pangasionodon hypophthalmus). Jurnal Akuakultur Rawa Indonesia, 8(2): 150-163.

Kusbiantoro, D., dan Y. Purwaningrum. (2018). Pemanfaatan Kandungan Metabolit Sekunder pada Tanaman Kunyit dalam Mendukung Peningkatan Pendapatan Masyarakat. Jurnal Kultivasi 17 (1): 544-549.

Kusdarwati, R., Kismiyati, Sudarno, H. Kurniawan, Y.T. Prayogi. (2017). Isolation and Indentification of Aeromonas hydrophila and Saprolegnia sp. on Catfish (Clarias gariepinus) in Floating cages in Bozem Moro Krembangan Surabaya. Journal IOP Conference Series: Earth and Environmental Science 55 (1): 1-7

Lestari, M. D., M. Arief., W. H. Satyantini. (2019). Addition of Curcuma (Curcuma xanthorrhiza) as An Antioxidant On African Catfish (Clarias gariepinus) Commercial Fish Feeding. International Journal of Civil 
Engineering and Technology (IJCIET) 10 (5): 380-385

Muchdar, F., dan Juharni. (2017). Penambahan Ekstrak Kunyit (Curcuma domestica) terhadap Pertumbuhan Benih Ikan Nila (Oreochromis niloticus). Prosiding Seminar Nasional Kemaritiman dan Sumberdaya PulauPulau Kecil, 1(1): 20-26

Pane, N.S., Hasim, Mulis. (2018). Perendaman Ekstrak Kunyit Terhadap Ikan Nila yang Terinfeksi Bakteri Aeromonas hydrophila. Jurnal Ilmiah Perikanan dan Kelautan 6 (1): 11-18

Pangestika, D., Erna M., Imam D. M. (2012). Pengaruh Pemberian Kunyit (Curcuma domestica Val.) Terhadap Aktivitas Fagositosis Makrofag pada Mencit BALB/C yang Diinokulasi Bakteri Listeria monocytogenes. Jurnal Sains Medika 4 (1): 63-70

Preanger C., Iwan H. U., I Made K. (2016). Gambaran Ulas Darah Ikan Lele Di Denpasar Bali. Jurnal Indonesia Medicus Veterinus, 5 (2): 96-103

Pujianti, N.A., Jaelani A., Widianingsih N. (2013). Penambahan Tepung Kunyit (Curcuma domestica) dalam Ransum terhadap Daya Cerna Protein dan Bahan Kering pada Ayam Pedaging. Jurnal Ilmu Pertanian, 36(1): 37-41

Purbomartono, C., Dini S.M., Danang P. (2019). Respon Imun Non-spesifik Ikan Gurami (Opshronemus gouramy) yang Diberi Fucoidan dari Ekstrak Rumput Laut Cokelat (Padina sp.). Jurnal Sainteks 16 (1): 9-17

Rizkiyah, U. (2018). Pengaruh Pemberian Multivitamin dalam Pakan terhadap Respons Imun Non-Spesifik Ikan Lele Dumbo (Clarias gariepinus). Skripsi. FKIP Universitas Muhammadiyah Purwokerto. $35 \mathrm{hlm}$.

Rustikawati, I. (2012). Efektifitas Esktrak Sargassum sp. terhadap Diferensiasi Leukosit Ikan Nila (Orechromis niloticus) yang Diinfeksi S. Iniae. Jurnal Akuatika 3 (2): 123-134.
Shan, C.Y., dan Y. Iskandar. (2018). Studi Kandungan Kimia dan Aktivitas Farmakologi Tanaman Kunyit (Curcuma longa L.). Jurnal Farmaka 16 (2): 547-555

Simorangkir, R., Sarjito, dan A.H.C. Haditomo. (2020). Pengaruh Ekstrak Bawang Putih (Allium sativum) terhadap Tingkat Pencegahan Infeksi Bakteri Vibrio harveyi dan Kelulushidupan Ikan Nila Salin (Oreochromis niloticus). Jurnal Sains Akuakultur Tropis, 4 (2): 139-147.

Susantie D., dan U.N. Manurung. (2019). Penambahan Ragi Roti (Saccharomyces cereviceae) dan Kunyit (Curcuma domestica Val) pada Pakan untuk Meningkatkan Pertumbuhan dan Imunitas Ikan Budidaya di Pulau Kawio Kabupaten Kepulauan Sangihe. Jurnal Ilmiah Tatengkorang 3 (1): 66-71

Syaieba, M., I. Lukistyowati, dan H. Syawal. (2019). Description of Leukocyt of Patin Siam (Pangasius hypopthalmus) That Feed by Addition of Harumanis Mango Seeds (Mangifera indica L.). Asian Journal of Aquatic Sciences, 2 (3): 235-246.

Titrawani. (2014). Gambaran Darah Ikan Paweh (Osteochilus hasselti C.V.) dari Danau Lubuk Siam, Kecamatan Siak Hulu, Kabupaten Kampar. Jurnal Biologi, 7 (1): 28-34.

Wahjuningrum, D., M.N. Ikhsan, Sukenda, Y. Evan. (2014). Penggunaan Ekstrak Kunyit (Curcuma domestica V.) sebagai Pengendali Infeksi Edwarsilla tarda pada Ikan Lele. Jurnal Akuakultur Indonesia 13 (1): 1-10

Wintoko, F., S. Agus, H. Siti, dan A. Mahrus. (2013). Imunogenitas Heat Killed Vaksin Inaktif Aeromonas hydrophila Pada Ikan Mas (Cyprinus carpio). Jurnal Rekayasa dan Teknologi Budidaya Perairan, 2 (1): 205-210 